\title{
Review \\ ZIKV Infection and miRNA Network in Pathogenesis and Immune Response
}

\author{
Carolina Manganeli Polonio ${ }^{1,2}$ (D) and Jean Pierre Schatzmann Peron $1,2,3, *$ (D) \\ 1 Neuroimmune Interactions Laboratory, Department of Immunology, University of São Paulo, \\ São Paulo 05508-000, Brazil; cmpolonio@usp.br \\ 2 Laboratory of Neuroimmunology of Arboviruses, Scientific Platform Pasteur-USP (SPPU), \\ University of São Paulo, São Paulo 05508-020, Brazil \\ 3 Immunopathology and Allergy Post Graduate Program, School of Medicine, University of São Paulo, \\ São Paulo 01246-000, Brazil \\ * Correspondence: jeanpierre@usp.br
}

check for updates

Citation: Polonio, C.M.; Peron, J.P.S. ZIKV Infection and miRNA Network in Pathogenesis and Immune Response. Viruses 2021, 13, 1992. https://doi.org/10.3390/v13101992

Academic Editors: Deborah H. Fuller and Heidi Drummer

Received: 15 August 2021

Accepted: 28 September 2021

Published: 4 October 2021

Publisher's Note: MDPI stays neutral with regard to jurisdictional claims in published maps and institutional affiliations.

Copyright: (c) 2021 by the authors. Licensee MDPI, Basel, Switzerland. This article is an open access article distributed under the terms and conditions of the Creative Commons Attribution (CC BY) license (https:// creativecommons.org/licenses/by/ $4.0 /)$.

\begin{abstract}
Over the years, viral infections have caused severe illness in humans. Zika Virus (ZIKV) is a flavivirus transmitted by mosquito vectors that leads to notable neurological impairment, whose most dramatic impact is the Congenital ZIKV Syndrome (CZS). ZIKV targets neuronal precursor cells leading to apoptosis and further impairment of neuronal development, causing microcephaly, lissencephaly, ventriculomegaly, and calcifications. Several regulators of biological processes are involved in CZS development, and in this context, microRNAs (miRNAs) seem to have a fundamental role. miRNAs are important regulators of protein translation, as they form the RISC silencing complex and interact with complementary mRNA target sequences to further post-transcriptional repression. In this context, little is known about their participation in the pathogenesis of viral infections. In this review, we discuss how miRNAs could relate to ZIKV and other flavivirus infections.
\end{abstract}

Keywords: microRNAs; ZIKV; flavivirus; viral infection

\section{Introduction}

Zika virus (ZIKV) is an arbovirus of the Flaviviridae family first isolated in 1947 from sentinel Rhesus sp. monkeys and Aedes africanus mosquitoes at the Ziika forest in Uganda, Africa [1]. ZIKV has a symmetrical structure, enveloped icosahedral nucleocapsid, and a $10 \mathrm{~Kb}(+)$ single-stranded RNA genome that encodes three structural proteins: Capsid (C), Pre-membrane (Pr-M), and Envelope (Env), and seven non-structural proteins: NS1, NS2a-2b, NS3, NS4a-4b and NS5 [2,3].

Previously, the potential for a viral outbreak was neglected, as it caused rare and mild infections in humans in Africa and Asia [4]. Later, outbreaks were identified elsewhere, such as Yap Island in Micronesia [5], French Polynesia in 2014 [6], Tahiti in 2013 [7], and New Caledonia in 2014 [8]. The main signs and symptoms known at the time included fever $\left(37.8-39.5^{\circ} \mathrm{C}\right)$, headaches, arthralgia of the hands and feet, conjunctivitis, and skin rash [5].

As of the first half of 2015, a generalized ZIKV epidemic occurred in South and Central America, with the northeast of Brazil being the most affected region. It is known that ZIKV causes Guillain-Barré Syndrome in adults [9] and congenital ZIKV syndrome (CZS) in fetuses infected during pregnancy, leading to severe neurological complications, including microcephaly, lissencephaly, ventriculomegaly, and cortical calcifications, associated or not with arthrogryposis, intrauterine growth restriction (IUGR), uveitis and retinal degeneration [10-12]. Unfortunately, most of these neurological modifications are irreversible and occurring in $6-12 \%$ of infected pregnant women $[13,14]$. Furthermore, neurological complications were also demonstrated in babies born without microcephaly [15-17].

Genetic differences, mainly related to antiviral immune response and neurodevelopment may directly influence susceptibility to infection $[18,19]$. Many of these genes 
code for proteins involved in signaling pathways, as adaptor proteins and transcription factors. Importantly, these molecules may be a target of post-transcriptional or posttranslational regulation when microRNAs (miRNAs) may have a fundamental role. The regulatory capacity of miRNAs has been described over the years in several animals and plants species [20]. Their participation has been studied in different diseases, such as cancer [21-23], diabetes [24,25], multiple sclerosis [26-28], and viral infections, including infections by neurotropic flaviviruses $[29,30]$.

Although the Brazilian Ministry of Health declared the end of the Public Health Emergency of National Importance (ESPIN) caused by ZIKV in 2017, neurological impairment leads to serious consequences for children, making them dependent and hindering their development and insertion into society. Therefore, understanding molecular mechanisms of susceptibility provides important knowledge for the development of vaccines or therapeutic interventions. In this review, we discuss how miRNAs may regulate important mRNAs to influence the outcome of ZIKV infection.

\section{ZIKV and Neurological Impairment}

ZIKV has been proven to cause neurological impairment by several studies using human samples and different experimental models. The first major evidence that ZIKV causes microcephaly came in 2015 [31]. The post-mortem analysis of an infected fetus indicated IUGR, numerous cortical and subcortical calcifications, moderate ventriculomegaly, and $26 \mathrm{~cm}$ brain perimeter, indicating microcephaly (control $\leq 32 \mathrm{~cm} \pm \mathrm{SD}$ ), associated with the presence of ZIKV RNA in the brain, suggesting a neurotropism. In addition, the histological and cellular analysis showed astrogliosis in the subarachnoid space related to viral particles present in neurons. Following studies corroborated these findings and demonstrated the presence of ZIKV in the amniotic fluid [32], placenta [33], cerebrospinal fluid (CSF) [34], and retinas [35] of babies with microcephaly.

Three studies were pioneers demonstrating susceptibility to infection and neurological damage [36-38]. One study used pregnant females, which comprised of interferon alpha/beta receptor subunit 1 (IFNAR1) ${ }^{-1}$ - or wild type (WT) mice treated with IFNAR1 receptor blocking antibodies (clone MAR1-5A3). The mice were infected subcutaneously with $10^{3}$ focus forming units (FFU) at embryonic day (E) E6.5 and E7.5 and pups were analyzed at E13.5 and E15.5 showing fetal resorption, IUGR, pallor, presence of necrotic tissue, and ZIKV in pups' placenta and brain tissue analyses [36]. Another group performed ZIKV infection via cerebroventricular route at E13.5 and analyzes at E16.5, which showed that ZIKV infected ventricular and subventricular zone where most neuronal precursors cells (NPCs) are found [37]. A third study was published by our group [38], demonstrating that WT pups born from pregnant Swiss James Lambert (SJL) infected mice presented IUGR characterized by reduced weight, size, length, height, and biparietal measurement. Histological analysis showed a decrease in the cerebral cortex, with nuclear vacuolization, chromatin marginalization in neurons from the cortex, thalamus, and hypothalamus, which was not observed in the cerebellum and hippocampus.

Monkey models have further ratified the neurological damage caused by ZIKV. Rhesus and adult cynomolgus monkeys were susceptible to infection, as viral RNA was found in plasma, saliva, CSF, brain, female and male reproductive tracts, semen, and transiently in vaginal secretions [39]. It has also been shown that non-pregnant and pregnant Rhesus monkeys remain viremic for 21 and up to 57 days after infection [40]. Also, the virus was persistent in the CNS and lymph nodes due to positive regulation of mammalian target of rapamycin (mTOR), pro-inflammatory and anti-apoptotic signaling pathways, as well as negative regulation of extracellular matrix signaling pathways [41].

Vertical transmission-related studies showed that intravenous or intra-amniotic infection during the second trimester-pregnant monkeys leads to high levels of ZIKV in placental and fetal tissues, especially in the brain, which exhibited calcifications and reduced numbers of NPCs [42]. Infected monkeys at the beginning of pregnancy exhibited more complex neuropathies, such as cerebral microcalcifications, hemorrhage, necrosis, 
vasculitis, gliosis, and NPCs apoptosis, and also magnetic resonance analyses indicated damage to the deep gray substance [43]. In addition, abnormal oxygen transport within the placenta has been observed as a result of uterine vasculitis and placental villous damage caused by ZIKV [44].

These results clearly showed that ZIKV crosses the placenta and has a tropism for the fetal brain, leading to important tissue damage. It has been shown that ZIKV infects NPCs and neurons, both in vitro and in vivo, inducing cell death by autophagy and apoptosis, as evidenced by active caspase- 3 expression analysis. In addition, the expression profile of 88 cell death-related genes showed that ZIKV positively regulates genes such as Bmf, Irgm1, Bcl2, Htt, Casp6, and Abl1, and negatively Gadd45a, Tnfrsf11b, Fasl, Atg12, Bcl2l11, and Dffa in the brain of SJL neonates born from ZIKV infected pregnant mice compared to uninfected mothers [38]. Moreover, a reduction in the cortical layer was observed due to the death of NPCs $\mathrm{TUJ}^{+}, \mathrm{SOX}-2^{+}$, and TBR-1 ${ }^{+}$, specific markers of NPCs that originate neurons and glial cells, evidenced by in vitro studies using cerebral organoids or mini-brains $[38,45,46]$.

Although NPCs and neurons are the most affected cells by ZIKV infection, astrocytes deserve attention in their participation during its pathogenesis [47]. Even though little is known about the role of infected glial cells in CZS development, it has been shown that astrocytes can be infected by the virus and may play a fundamental role in the pathogenesis of microcephaly [48].

Reactive astrocytes have been identified in fetuses at 32 weeks of gestation in the brain regions affected by the virus [31]. The impaired functioning of astrocytes contributes significantly during microcephaly development, as it affects cortex growth due to impairment in neurogenesis and gangliogenesis [49,50]. Astrocytes infected by ZIKV present dysregulation in protein translation, glucose metabolism, synaptic control as well as in cell migration and differentiation $[47,51,52]$. Moreover, it has been shown that astrocytes are more susceptible to infection by ZIKV than neurons since they tolerate greater viral loads, suffer less apoptosis, and, consequently, allow a greater viral replication [53].

\section{MicroRNAs}

miRNAs are small non-coding and regulatory single-stranded RNA molecules that perform post-transcriptional regulation of mRNAs sequences by binding to $3^{\prime}$ or $5^{\prime}$ untranslated regions (UTR) that destabilize and block translation of encoding proteins [54]. It is known that more than $60 \%$ of human genes that encode proteins have at least one conserved miRNA binding site, and several non-conserved sites [55,56]. Therefore, miRNAs expression must be well controlled, since their dysregulation is associated with pathologies, including those associated with neurological development [57].

miRNAs are transcribed and processed (Figure 1) from long primary chains (primiRNA) with more than a thousand nucleotides [54]. They are processed in the nucleus by a type III endoribonuclease (Drosha) and its cofactor DiGeorge Syndrome Critical Region Gene (DGRC8) generating the shorter precursor miRNA (pre-miRNA) with approximately 65 nucleotides long [58,59]. Following, the pre-miRNA is transferred to the cytosol by exportin 5 protein [60-62]. In the cytosol, pre-miRNA is processed by RNase III (Dicer) and RNA binding cofactor TAR RNA-Binding Protein (TRBP) in a short double-stranded miRNA with 20-24 base pairs, known as miRNA duplex [63]. The Argonaute (AGO2) is further recruited [64] forming the miRNA-containing RNA-induced silencing complex (miRISC) [65], where the mature miRNA (guide strand) [63,66] pairs with several complementary mRNA sequences to interfering in encoded proteins production [67]. 


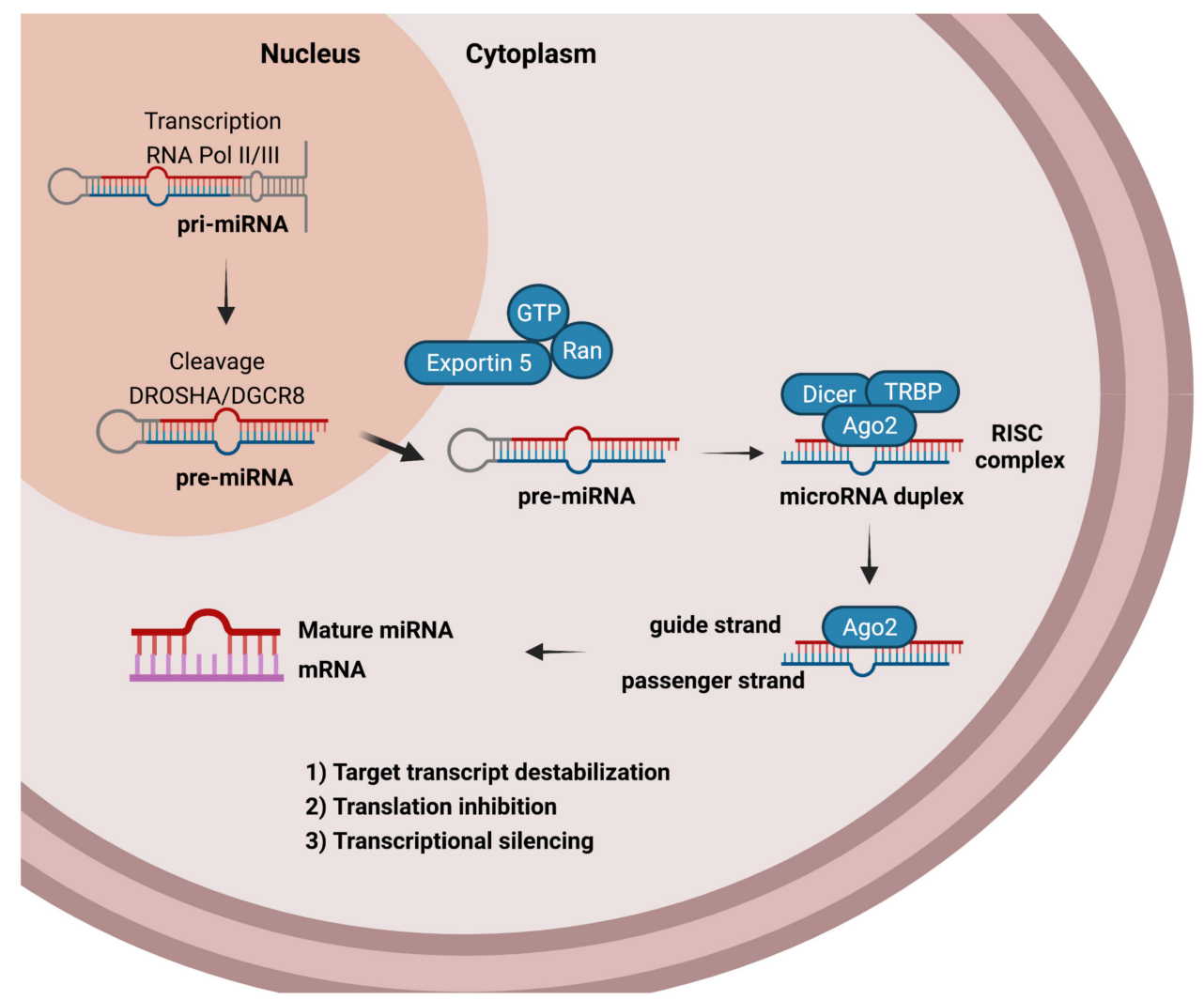

Figure 1. Overview of miRNA biogenesis. Biogenesis consists of the miRNA gene transcription and maturation that involves the following steps: Pri-miRNA processing by DROSHA; Processing of pre-miRNA by DICER; Other modifications to produce mature miRNA and RISC complex formation to further mature miRNAs regulate mRNA and consequently interfere in protein production. Figure created by authors using BioRender.com.

The mechanisms of miRNAs action are divided into (1) target transcript destabilization, (2) translation inhibition, and (3) transcriptional silencing. Destabilization is represented by a) deadenylation followed by mRNA $5^{\prime} \mathrm{CAP}$ removal, once AGO2 is associated with GW182, which recruits CCR4-NOT complex and promotes the removal of poly-A tail, leading to mRNA destabilization and further mRNA degradation by exoribonucleases [68]. The translation inhibition is represented by (a) AGO competition for $5^{\prime} \mathrm{CAP}$, once miRNAs lead AGO2 to mRNA, which competes for the $5^{\prime} \mathrm{CAP}$, preventing mRNA and ribosomes association [69,70]; (b) blocking translation initiation, preventing poly-A tail interaction with poly-A binding protein $\mathrm{C} 1$ (PABPC1) and 5'CAP interaction with Eukaryotic Translation Initiation Factor 4E/4G (eID4E/eIF4G) [71]; and (c) dissociation of ribosomes, in which some miRNAs lead to early disassembly of ribosomes [72]. Finally, miRNAs perform transcriptional silencing that involves RNA processing bodies ( $p$-bodies) that are cytoplasmic ribonucleoprotein aggregates [73]. miRNAs directly target mRNAs to $p$-bodies, where they are temporarily and reversibly repressed or destabilized [74].

This provides evidence for the complex translational regulation performed by miRNAs, which are important in different scenarios as regulatory molecules for several biological processes, making them biomarkers for detection and progression of diseases, as well as a target for therapeutic intervention [75].

\section{Neurodevelopment-Related miRNAs and ZIKV Infection}

ZIKV leads to irreversible neurological damage and, in this context, the study of molecules that interfere in the neurodevelopment becomes of great importance during CZS development. miRNAs have also been studied during embryonic development. Interestingly, Dicer deficient animals are not viable and suffer spontaneous abortion around the seventh day of gestation. Currently, conditional mice are available, in which Dicer 
deletion is performed by Cre-lox recombination. Using this system, it was possible to demonstrate that miRNAs are involved in neurodevelopment since dopaminergic neurons without Dicer undergo progressive apoptosis [76]. In addition, Dicer deficient mice are not able to generate viable embryonic stem cells (ESC) and maintain this population during mouse development [76].

Conversely, studies are demonstrating the importance of miR-9 for brain development [77], radial glia proliferation, and also neuronal and glial differentiation [78]. MiR-9 is highly conserved in all mammals, and, in rodents, it is specifically expressed in the brain, mostly in NPCs during neuronal differentiation. MiR-9 KO mice have smaller brain hemispheres and olfactory bulbs compared to WT animals, associated with decreased cerebral cortex and ventriculomegaly, characteristics similar to microcephaly [79,80]. In addition, it has been shown that cortex neuronal differentiation involves intermediate progenitor cells specificity and their development is regulated by several miRNAs, including miR-9 [81,82].

There are several genes related to autosomal recessive microcephaly (MCPH-Microcephaly Primary Hereditary). There are $12 \mathrm{MCPH}$ loci (MCPH1-MCPH12) that have been mapped and contain the following genes: Microcephalin, WDR62; CDK5RAP2; CASC5; ASPM; CENPJ; STIL; CEP135; CEP152; ZNF335; PHC1, and CDK6. It is believed that these genes lead to disease phenotype due to premature chromosomal condensation, damaged DNA, disturbed microtubule dynamics, transcriptional control, and hidden centro-somatic mechanisms that regulate the number of neurons produced by neuronal precursor cells $[83,84]$.

Interestingly, host RNA-binding proteins interact with viral genome UTRs regulating viral replication and translation [85]. An important regulator of NPC development, the RNA-binding protein Musashi-1 (MSI1), interacts with the ZIKV genome and unexpectedly improves viral replication [86]. It was also shown that during neurodevelopment, Musashi1 interacts with MCPH-1 $3^{\prime}$ UTR to regulate its expression to normal brain functioning. Interestingly, during ZIKV infection, Musashi-1 binds to the ZIKV 3'UTR genome to enable viral replication, and consequently, leads to impaired neurodevelopment. Recently, through computational analysis, it has been hypothesized that the ZIKV genome activates six host miRNAs that result in modifications based on neuronal genetic pathways that share significant mutual homologies with the $12 \mathrm{MCHP}$ genes [83].

The importance of miRNAs during ZIKV infection has been described by several groups. A Brazilian group, using human neurospheres, showed that ZIKV replication stops the proliferation and differentiation of neuronal cells [87]. In addition, ZIKV upregulates a target network related to viral replication and downregulates molecules associated with the cell cycle and neuronal differentiation. Still in this work, it was demonstrated that ZIKV infection modulates pathways involved in RNA processing (DDX6, PCBP2), miRNAs biogenesis (DGCR8, XPO1), regulation of translation initiation (eIF3c), and proteins, such as splicing factors (SFPQ, PRP8), ribosomal proteins (RPS6KA5, RPL28), proteins related to innate immune response (TLR4) and neuronal development (NEUROD1, SATB2).

Interestingly, ZIKV capsid directly interacts with Dicer to improve infection. Using a capsid mutant (H41R) it was demonstrated that ZIKV loses the ability to inhibit neurogenesis and corticogenesis. Therefore, the interaction between ZIKV H41R capsid and Dicer is necessary for the pathogenesis and the characteristic lesions [88].

Moreover, the ZIKV envelope (E) modulates the expression of the host's miRNAs and, using bioinformatics tools, it was shown that the pathways involved were related to cell cycle and development processes [89]. ZIKV E protein causes NSCs quiescence by increasing the number of cells in the G0/G1 cell cycle phase. Also, the E protein induces NSCs apoptosis, further impairing neuronal differentiation and migration.

Recently, post-mortem analysis of brain tissue from babies born with severe CZS showed an upregulation of miR-145 and miR-148a, and in silico analysis indicated that their target genes are involved in neurodevelopment pathways, such as glial differentiation, neurogenesis, and cerebral cortex development [90].

In response to ZIKV infection, NPCs release extracellular vesicles containing miRNAs, such as miR-4792, that modulate genes related to oxidative stress and neurodevelopmental 
processes [91]. Through RNA-sequencing, miR-sequencing, and AGO-iCLIP-sequencing, it was shown that ZIKV increases miR-124 expression acting over TFRC mRNA to further cell proliferation attenuation [92]. In primary murine neurons, the Puerto Rico ZIKV strain (PRVABC59) modulates miR-29a, miR-124, miR-155, and miR-203 which have a role in increasing antiviral immune response and brain damage [93]. In human astrocytes, ZIKV infection increased miR-17-5p, miR-30e-3p, and miR-30e-5p expression, regulating genes involved in cell cycle and immune response [94] (Table 1).

In addition, ZIKV genome sequencing also expresses 47 miRNAs that target pathways involved in cell signaling regulation, neurological functions, and fetal development assisting in the establishment of microcephaly caused by ZIKV [95]. However, ZIKV negatively regulates essential miRNAs during CNS development, neuronal and glial differentiation, and positively regulates miRNAs that degrade essential genes in the same processes for the normal functioning of the organism. This confirms the harmful role of ZIKV in the CNS. These findings highlight the importance of miRNAs during ZIKV infection, correlating it with the pathogenesis of microcephaly caused by the virus.

Table 1. miRNAs and neurodevelopment.

\begin{tabular}{ccc}
\hline miRNA & Virus & Cell Source \\
\hline$\uparrow_{\text {miR-9 [77-80] }}$ & $\uparrow_{\text {Neurodevelopment }}$ & Brain, mostly human NPC \\
\hline$\uparrow_{\text {miR-145; miR-148 [90] }}$ & $\downarrow_{\text {Neurodevelopment }}$ & Human brain tissue \\
\hline$\uparrow_{\text {miR-4792 [91] }}$ & $\downarrow_{\text {Neurodevelopment }}$ & Human NPCs \\
\hline$\uparrow_{\text {miR-29; miR-124; miR-155; miR-203 [92,93] }}$ & $\uparrow_{\text {Brain damage }}$ & Primarine neurons \\
\hline
\end{tabular}

\section{Antiviral Immune Response and miRNA}

There are many studies emphasizing miRNAs importance during flavivirus infection. In some cases, miRNAs are found upregulated by infection leading to immune response inhibition [96] (Table 2). For example, the Japanese encephalitis virus (JEV), which infects neurons and microglia cells causing neuronal damage and inflammation, modulates miRNAs expression that downregulates genes involved in cellular immune response and antiviral genes [96]. The JEV infection increases miR-146a expression, which downregulates TRAF6, IRAK1, IRAK2, and STAT1 genes. In addition, miR-146a suppresses activation of NF- $\mathrm{kB}$ and Jak-STAT pathway, resulting in negative regulation of ISGs (IFIT-1 and IFIT-2) and facilitating viral replication [96]. Interestingly, it has been shown that NS3 from JEV degrades miR-466d increasing viral replication [97]. Moreover, miRNAs assist viral replication directly, such as miR-21, which promotes DENV replication in human liver carcinoma cells [98].

Table 2. miRNAs that favors viral replication and decrease immune response.

\begin{tabular}{|c|c|c|}
\hline miRNA & Virus & Immune Response Component \\
\hline$\widehat{T}_{\mathrm{miR}-146}$ [96] & TJEV replication & $\begin{array}{l}\text { VRAF6; IRAK1/2; STAT-1 } \\
\text { NF-кB resulting a decreasing of IFIT1/2 }\end{array}$ \\
\hline $\begin{array}{l}\downarrow \mathrm{NS3} \text { of JEV } \\
\text { miR-466d [97] }\end{array}$ & TJEV replication & \\
\hline$\widehat{T}_{\operatorname{miR}-21}[98]$ & DENV replication & \\
\hline
\end{tabular}


On the other hand, miRNA overexpression may be beneficial to the host during flaviviruses infections, leading to decreased viral replication. For example, miR-155 upregulation in CHME3 cells, a microglial cell line, results in a significant reduction of JEV replication by decreasing NF- $\mathrm{kB}$ pathway genes and STAT-1, at the same time increases microglial activation [99]. Other miRNAs favor antiviral immune responses, preventing virus spreading, such as during JEV infection that upregulates miR-19b triggering Ring Finger Protein 125 (RNF125) inhibition, a negative regulator of RIG-I signaling. Thus, miR-19b increases inflammatory response, including type I IFNs production, and decreases glial activation and neuronal damage [100] (Table 3).

Table 3. miRNAs that increase immune response.

\begin{tabular}{|c|c|c|}
\hline miRNA & Virus & Immune Response Component \\
\hline TmiR-155 [99] & $\downarrow$ & $\begin{array}{l}\text { INF-кB and STAT-1 pathway genes } \\
\text { Microglial activation }\end{array}$ \\
\hline TิmiR-19b [100] & $\downarrow$ & $\begin{array}{l}\text { RNF124 and consequently increase RIG-I signaling. } \\
\text { Type I IFN production }\end{array}$ \\
\hline
\end{tabular}

Interestingly, miRNAs are very promiscuous. The same miRNA modulates different mRNAs from the same signaling pathway, while different miRNAs interfere in the same mRNA. In this way, miRNAs assume ambiguous roles under different situations. Therefore, some flaviviruses could use miRNAs to suppress the immune response and, consequently favor its replication, while other flaviviruses lead to host miRNAs expression that will favor the immune response against the virus.

In this context, it is known that ZIKV decreases the immune response, but so far, none of the described mechanisms involved miRNAs [101-103]. Hence, it is plausible to think that ZIKV modulates miRNAs that will modulate genes of the antiviral immune response. This may either impact viral biology or the pathogenesis of the infection.

\section{Concluding Remarks}

In summary, we highlight miRNAs as potential regulators of biological processes in face of viral infections, including ZIKV (Figure 2). Thus, they modulate essential pathways for brain development, neurogenesis, apoptosis, autophagy, as well as inflammatory and antiviral responses. Here, we showed many in silico studies describing modulated miRNAs and their targets. However, there is still a lack of knowledge about specific miRNA targets and their effects during ZIKV infection. Therefore, more in-depth research needs to be carried out to further add to the knowledge of ZIKV infection and microcephaly caused by vertical transmission, assisting in the development of future therapeutic interventions. 

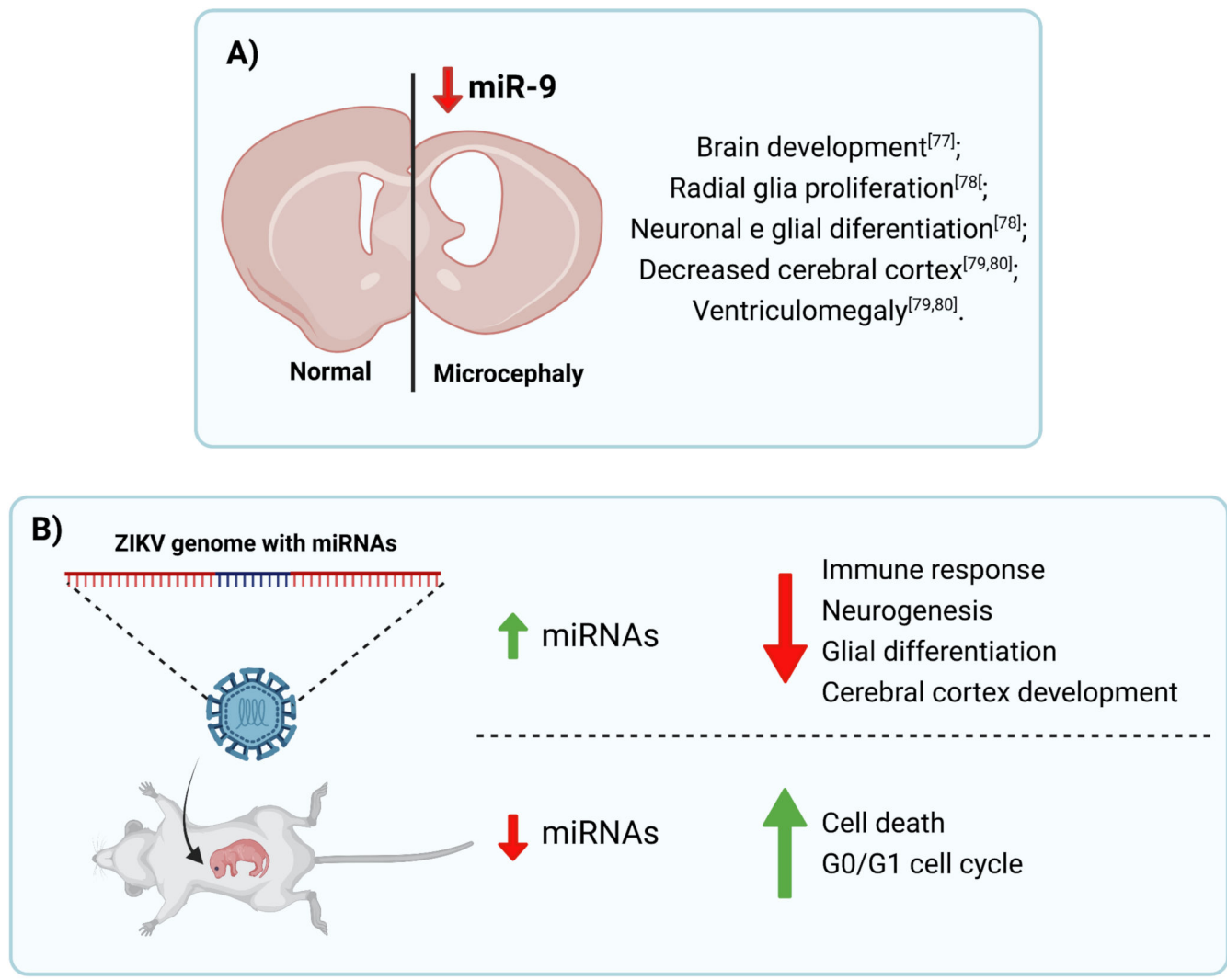

Figure 2. MiRNAs post-transcription regulation. miRNAs control (A) brain development and different pathway involved (B) in antiviral immune response, neurogenesis, cell death, and cell cycle in response to ZIKV and other flavivirus infections. Figure created by authors using BioRender.com.

Author Contributions: C.M.P. wrote the manuscript and designed the figures and tables. J.P.S.P. supervised and edited the manuscript. All authors have read and agreed to the published version of the manuscript.

Funding: J.P.S.P. is a recipient of FAPESP grants \#2017/26170-0; \#2017/22504-1; \#2020/06145-4. C.M.P is a recipient of FAPESP fellowship \#2017/11828-0; \#2019/13731-0.

Institutional Review Board Statement: Not applicable.

Informed Consent Statement: Not applicable.

Acknowledgments: We would like to thank all the members of the Neuroimmune Interactions Laboratory for their partnership during these years.

Conflicts of Interest: The authors declare no conflict of interest.

\section{References}

1. Dick, G.W. Zika virus (I). Isolations and serological specificity. Trans. R. Soc. Trop. Med. Hyg. 1952, 46, 509-520. [CrossRef]

2. Tan, T.Y.; Fibriansah, G.; Kostyuchenko, V.A.; Ng, T.S.; Lim, X.X.; Zhang, S.; Lim, X.N.; Wang, J.; Shi, J.; Morais, M.C.; et al. Capsid protein structure in Zika virus reveals the flavivirus assembly process. Nat. Commun. 2020, 11, 895. [CrossRef] [PubMed]

3. Hasan, S.S.; Sevvana, M.; Kuhn, R.J.; Rossmann, M.G. Structural biology of Zika virus and other flaviviruses. Nat. Struct. Mol. Biol. 2018, 25, 13-20. [CrossRef] [PubMed]

4. Paixão, S.; Barreto, F.; da Glória, M.T.; Costa, M.C.N.; Rodrigues, L.C. History, epidemiology, and clinical manifestations of Zika: A systematic review. Am. J. Public Health 2016, 106, 606-612. [CrossRef]

5. Duffy, M.R.; Chen, T.-H.; Hancock, W.T.; Powers, A.M.; Kool, J.L.; Lanciotti, R.S.; Pretrick, M.; Marfel, M.; Holzbauer, S.; Dubray, C.; et al. Zika virus outbreak on Yap Island, Federated States of Micronesia. N. Engl. J. Med. 2009, 360, 2536-2543. [CrossRef] [PubMed]

6. Cao-Lormeau, V.-M.; Roche, C.; Teissier, A.; Robin, E.; Berry, A.-L.; Mallet, H.-P.; Sall, A.A.; Musso, D. Zika virus, French Polynesia, South Pacific, 2013. Emerg. Infect. Dis. 2014, 20, 5-6. [CrossRef] [PubMed] 
7. Wæhre, T.; Maagard, A.; Tappe, D.; Cadar, D.; Schmidt-Chanasit, J. Zika virus infection after travel to Tahiti, December 2013. Emerg. Infect. Dis. 2014, 20, 1412-1414. [CrossRef] [PubMed]

8. Roth, A.; Mercier, A.; Lepers, C.; Hoy, D.; Duituturaga, S.; Benyon, E.; Guillaumot, L.; Souares, Y. Concurrent outbreaks of Dengue, Chikungunya and Zika virus infections-An unprecedented epidemic wave of mosquito-borne viruses in the Pacific 2012-2014. Eurosurveillance 2014, 19, 1-8. [CrossRef]

9. Oehler, E.; Watrin, L.; Larre, P.; Leparc-Goffart, I.; Lastãre, S.; Valour, F.; Baudouin, L.; Mallet, H.P.; Musso, D.; Ghawche, F. Zika virus infection complicated by Guillain-Barré syndrome-Case report, French Polynesia, December 2013. Eurosurveillance 2014, 19,7-9. [CrossRef]

10. Brasil, P.; Junior, J.P.P.; Moreira, M.E.; Nogueira, R.M.R.; Damasceno, L.; Wakimoto, M.; Rabello, R.S.; Valderramos, S.G.; Halai, U.-A.; Gabaglia, C.R.; et al. Zika virus infection in pregnant women in Rio de Janeiro. N. Engl. J. Med. 2016, 375, 2321-2334. [CrossRef]

11. Ventura, C.V.; Maia, M.; Dias, N.; Ventura, L.O.; Belfort, R. Zika: Neurological and ocular findings in infant without microcephaly. Lancet 2016, 387, 2502. [CrossRef]

12. Polonio, C.M.; de Freitas, C.L.; Zanluqui, N.G.; Peron, J.P.S. Zika virus congenital syndrome: Experimental models and clinical aspects. J. Venom. Anim. Toxins Incl. Trop. Dis. 2017, 23, 1-9. [CrossRef] [PubMed]

13. Rasmussen, S.A.; Jamieson, D.J.; Honein, M.A.; Petersen, L.R. Zika virus and birth defects-Reviewing the evidence for causality. N. Engl. J. Med. 2016, 374, 1981-1987. [CrossRef]

14. França, G.V.A.; Schuler-Faccini, L.; Oliveira, W.K.; Henriques, C.M.P.; Carmo, E.H.; Pedi, V.D.; Nunes, M.L.; Castro, M.C.; Serruya, S.; Silveira, M.F.; et al. Congenital Zika virus syndrome in Brazil: A case series of the first 1501 livebirths with complete investigation. Lancet 2016, 388, 891-897. [CrossRef]

15. Vouga, M.; Pomar, L.; Panchaud, A.; Musso, D.; Baud, D. A critical analysis of the neurodevelopmental and neurosensory outcomes after 2 years for children with in utero Zika virus exposure. Nat. Med. 2019, 25, 1641-1642. [CrossRef]

16. Cranston, J.S.; Tiene, S.F.; Nielsen-Saines, K.; Vasconcelos, Z.; Pone, M.V.; Pone, S.; Zin, A.; Salles, T.S.; Pereira, J.P.; Orofino, D.; et al. Association between antenatal exposure to Zika virus and anatomical and neurodevelopmental abnormalities in children. JAMA Netw. Open 2020, 3, 209303. [CrossRef]

17. Zhao, Z.; Shang, Z.; Vasconcelos, Z.; Li, C.; Jiang, Y.; Zu, S.; Zhang, J.; Wang, F.; Yao, L.; Jung, J.U.; et al. Zika virus infection leads to variable defects in multiple neurological functions and behaviors in mice and children. Adv. Sci. 2020, 7, 1-10. [CrossRef]

18. Silva-Filho, J.L.; de Oliveira, L.G.; Monteiro, L.; Parise, P.L.; Zanluqui, N.G.; Polonio, C.M.; de Freitas, C.L.; Toledo-Teixeira, D.A.; de Souza, W.M.; Bittencourt, N.; et al. Gas6 drives Zika virus-induced neurological complications in humans and congenital syndrome in immunocompetent mice. Brain. Behav. Immun. 2021, 21, 1591.

19. Caires-Júnior, L.C.; Goulart, E.; Melo, U.S.; Araujo, B.S.H.; Alvizi, L.; Soares-Schanoski, A.; De Oliveira, D.F.; Kobayashi, G.S.; Griesi-Oliveira, K.; Musso, C.M.; et al. Discordant congenital Zika syndrome twins show differential in vitro viral susceptibility of neural progenitor cells. Nat. Commun. 2018, 9, 475-486. [CrossRef] [PubMed]

20. Bartel, D.P.; Lee, R.; Feinbaum, R. MicroRNAs: Genomics, biogenesis, mechanism, and function genomics. Cells 2004, 116, 281-297. [CrossRef]

21. Idichi, T.; Seki, N.; Kurahara, H.; Fukuhisa, H.; Toda, H.; Shimonosono, M.; Yamada, Y.; Arai, T.; Kijima, T.; Mataki, Y.; et al. Involvement of anti-tumor miR-124-3p and its targets in the pathogenesis of pancreatic ductal adenocarcinoma: Direct regulation of ITGA3 and ITGB1 by miR-124-3p. Oncotarget 2018, 9, 28849-28865. [CrossRef]

22. Li, X.; He, J.; Shao, M.; Cui, B.; Peng, F.; Li, J.; Ran, Y.; Jin, D.; Kong, J.; Chang, J.; et al. Downregulation of miR-218-5p promotes invasion of oral squamous cell carcinoma cells via activation of CD44-ROCK signaling. Biomed. Pharmacother. 2018, 106, 646-654. [CrossRef] [PubMed]

23. Paul, S.; Brahma, D. An integrated approach for identification of functionally similar microRNAs in colorectal cancer. IEEE/ACM Trans. Comput. Biol. Bioinf. 2017, 16, 183-192. [CrossRef] [PubMed]

24. Beltrami, C.; Simpson, K.; Jesky, M.; Wonnacott, A.; Carrington, C.; Holmans, P.; Newbury, L.; Jenkins, R.; Ashdown, T.; Dayan, C.; et al. Association of elevated urinary miR-126, miR-155, and miR-29b with diabetic kidney disease. Am. J. Pathol. 2018, 188, 1982-1992. [CrossRef] [PubMed]

25. Lei, H.; Li, H.; Tian, L.; Li, M.; Xin, Z.; Zhang, X.; Guan, R. Icariside II ameliorates endothelial dysfunction by regulating the MAPK pathway via miR-126/SPRED1 in diabetic human cavernous endothelial cells. Drug Des. Dev. Ther. 2018, 12, 1743-1751. [CrossRef]

26. Keller, A.; Leidinger, P.; Lange, J.; Borries, A.; Schroers, H.; Scheffler, M.; Lenhof, H.P.; Ruprecht, K.; Meese, E. Multiple sclerosis: microRNA expression profiles accurately differentiate patients with relapsing-remitting disease from healthy controls. PLoS ONE 2009, 4, 7440. [CrossRef] [PubMed]

27. Zhu, E.; Wang, X.; Zheng, B.; Wang, Q.; Hao, J.; Chen, S.; Zhao, Q.; Zhao, L.; Wu, Z.; Yin, Z. miR-20b suppresses Th17 differentiation and the pathogenesis of experimental autoimmune encephalomyelitis by targeting ROR $\gamma \mathrm{t}$ and STAT3. J. Immunol. 2014, 192, 5599-5609. [CrossRef] [PubMed]

28. Murugaiyan, G.; Da Cunha, A.P.; Ajay, A.K.; Joller, N.; Garo, L.P.; Kumaradevan, S.; Yosef, N.; Vaidya, V.S.; Weiner, H.L. MicroRNA-21 promotes Th17 differentiation and mediates experimental autoimmune encephalomyelitis. J. Clin. Investig. 2015, 125, 1069-1080. [CrossRef] 
29. Heiss, B.L.; Maximova, O.A.; Thach, D.C.; Speicher, J.M.; Pletnev, A.G. MicroRNA targeting of neurotropic flavivirus: Effective control of virus escape and reversion to neurovirulent phenotype. J. Virol. 2012, 86, 5647-5659. [CrossRef]

30. Diosa-Toro, M.; Echavarría-Consuegra, L.; Flipse, J.; Fernández, G.J.; Kluiver, J.; Van den Berg, A.; Urcuqui-Inchima, S.; Smit, J.M. MicroRNA profiling of human primary macrophages exposed to Dengue virus identifies miRNA-3614-5p as antiviral and regulator of ADAR1 expression. PLoS Negl. Trop. Dis. 2017, 11, 1-24. [CrossRef]

31. Mlakar, J.; Korva, M.; Tul, N.; Popović, M.; Poljšak-Prijatelj, M.; Mraz, J.; Kolenc, M.; Rus, K.R.; Vipotnik, T.V.; Vodušek, V.F.; et al. Zika virus associated with microcephaly. N. Engl. J. Med. 2016, 374, 951-958. [CrossRef]

32. Calvet, G.; Aguiar, R.S.; Melo, A.S.; Sampaio, S.A.; de Filippis, I.; Fabri, A.; Araujo, E.S.; de Sequeira, P.C.; de Mendonça, M.C.L.; de Oliveira, L.; et al. Detection and sequencing of Zika virus from amniotic fluid of fetuses with microcephaly in Brazil: A case study. Lancet Infect. Dis. 2016, 16, 653-660. [CrossRef]

33. Adibi, J.J.; Junior, E.T.A.M.; Cartus, A.; Beigi, R.H. Teratogenic effects of the Zika virus and the role of the placenta. Lancet Infect. Dis. 2016, 387, 1587-1590. [CrossRef]

34. Rozé, B.; Najioullah, F.; Signate, A.; Apetse, K.; Brouste, Y.; Gourgoudou, S.; Fagour, L.; Abel, S.; Hochedez, P.; Cesaire, R.; et al. Zika virus detection in cerebrospinal fluid from two patients with encephalopathy, Martinique, February 2016. Eurosurveillance 2016, 21, 1-4. [CrossRef] [PubMed]

35. Ventura, C.V.; Maia, M.; Bravo-Filho, V.; Góis, A.L.; Belfort, R. Zika virus in Brazil and macular atrophy in a child with microcephaly. Lancet 2016, 387, 228. [CrossRef]

36. Miner, J.J.; Cao, B.; Govero, J.; Smith, A.M.; Fernandez, E.; Cabrera, O.H.; Garber, C.; Noll, M.; Klein, R.S.; Noguchi, K.K.; et al. Zika virus infection during pregnancy in mice causes placental damage and fetal demise. Cell 2016, 165, 1081-1091. [CrossRef] [PubMed]

37. Li, C.; Xu, D.; Ye, Q.; Hong, S.; Jiang, Y.; Liu, X.; Zhang, N.; Shi, L.; Qin, C.-F.; Xu, Z. Zika virus disrupts neural progenitor development and leads to microcephaly in mice. Cell Stem Cell 2016, 19, 120-126. [CrossRef]

38. Cugola, F.R.; Fernandes, I.R.; Russo, F.B.; Freitas, B.C.; Dias, J.L.M.; Guimarães, K.P.; Benazzato, C.; Almeida, N.; Pignatari, G.C.; Romero, S.; et al. The Brazilian Zika virus strain causes birth defects in experimental models. Nature 2016, 534, 267-271. [CrossRef]

39. Osuna, C.E.; Lim, S.Y.; Deleage, C.; Griffin, B.D.; Stein, D.; Schroeder, L.T.; Omange, R.; Best, K.; Luo, M.; Hraber, P.T.; et al. Zika viral dynamics and shedding in rhesus and cynomolgus macaques. Nat. Med. 2016, 22, 1448-1455. [CrossRef] [PubMed]

40. Dudley, D.M.; Aliota, M.T.; Mohr, E.L.; Weiler, A.M.; Lehrer-Brey, G.; Weisgrau, K.L.; Mohns, M.S.; Breitbach, M.E.; Rasheed, M.N.; Newman, C.M.; et al. A rhesus macaque model of Asian-lineage Zika virus infection. Nat. Commun. 2016, 7, 12204. [CrossRef]

41. Aid, M.; Abbink, P.; Larocca, R.A.; Boyd, M.; Nityanandam, R.; Nanayakkara, O.; Martinot, A.J.; Moseley, E.T.; Blass, E.; Borducchi, E.N.; et al. Zika virus persistence in the central nervous system and lymph nodes of rhesus monkeys. Cell 2017, 169, 610-620. [CrossRef]

42. Coffey, L.L.; Keesler, R.I.; Pesavento, P.A.; Woolard, K.; Singapuri, A.; Watanabe, J.; Cruzen, C.; Christe, K.L.; Usachenko, J.; Yee, J.; et al. Intraamniotic Zika virus inoculation of pregnant rhesus macaques produces fetal neurologic disease. Nat. Commun. 2018, 9 , 2414. [CrossRef]

43. Martinot, A.J.; Abbink, P.; Afacan, O.; Prohl, A.K.; Bronson, R.; Hecht, J.L.; Borducchi, E.N.; Larocca, R.A.; Peterson, R.L.; Rinaldi, W.; et al. Fetal neuropathology in Zika virus-infected pregnant female rhesus monkeys. Cell 2018, 173, 1111-1122. [CrossRef] [PubMed]

44. Hirsch, A.J.; Roberts, V.H.J.; Grigsby, P.L.; Haese, N.; Schabel, M.C.; Wang, X.; Lo, J.O.; Liu, Z.; Kroenke, C.D.; Smith, J.L.; et al. Zika virus infection in pregnant rhesus macaques causes placental dysfunction and immunopathology. Nat. Commun. 2018, 9, 263. [CrossRef] [PubMed]

45. Garcez, P.P.; Loiola, E.C.; de Costa, R.M.; Higa, L.M.; Trindade, P.; Delvecchio, R.; Nascimento, J.M.; Brindeiro, R.; Tanuri, A.; Rehen, S.K. Zika virus impairs growth in human neurospheres and brain organoids. Science 2016, 352, 816-818. [CrossRef]

46. Qian, X.; Nguyen, H.N.; Song, M.M.; Hadiono, C.; Ogden, S.C.; Hammack, C.; Yao, B.; Hamersky, G.R.; Jacob, F.; Zhong, C.; et al. Brain-region-specific organoids using mini-bioreactors for modeling ZIKV exposure. Cell 2016, 165, 1238-1254. [CrossRef] [PubMed]

47. Sher, A.A.; Glover, K.K.M.; Coombs, K.M. Zika virus infection disrupts astrocytic proteins involved in synapse control and axon guidance. Front. Microbiol. 2019, 10, 596-616. [CrossRef]

48. Stefanik, M.; Formanova, P.; Bily, T.; Vancova, M.; Eyer, L.; Palus, M.; Salat, J.; Braconi, C.T.; Zanotto, P.M.d.A.; Gould, E.A. Characterization of Zika virus infection in primary human astrocytes. BMC Neurosci. 2018, 19, 5-12. [CrossRef]

49. DeAzevedo, L.C.; Fallet, C.; Moura-Neto, V.; Daumas-Duport, C.; Hedin-Pereira, C.; Lent, R. Cortical radial glial cells in human fetuses: Depth-correlated transformation into astrocytes. J. Neurobiol. 2003, 55, 288-298. [CrossRef]

50. Hansen, D.V.; Lui, J.H.; Parker, P.R.L.; Kriegstein, A.R. Neurogenic radial glia in the outer subventricular zone of human neocortex. Nature 2010, 464, 554-561. [CrossRef]

51. Schouest, B.; Peterson, T.A.; Szeltner, D.M.; Scheef, E.A.; Baddoo, M.; Ungerleider, N.; Flemington, E.K.; MacLean, A.G.; Maness, N.J. Transcriptional signatures of Zika virus infection in astrocytes. J. Neurovirol. 2021, 27, 116-125. [CrossRef] [PubMed]

52. Shereen, M.A.; Bashir, N.; Su, R.; Liu, F.; Wu, K.; Luo, Z.; Wu, J. Zika virus dysregulates the expression of astrocytic genes involved in neurodevelopment. PLoS Negl. Trop. Dis. 2021, 15, 1-24. [CrossRef] [PubMed] 
53. Jorgačevski, J.; Korva, M.; Potokar, M.; Lisjak, M.; Avšič-Županc, T.; Zorec, R. ZIKV strains differentially affect survival of human fetal astrocytes versus neurons and traffic of ZIKV-laden endocytotic compartments. Sci. Rep. 2019, 9, 8069. [CrossRef] [PubMed]

54. Axtell, M.J.; Westholm, J.O.; Lai, E.C. Vive la différence: Biogenesis and evolution of microRNAs in plants and animals. Genome Biol. 2011, 12, 221-233. [CrossRef] [PubMed]

55. Friedman, R.C.; Farh, K.K.H.; Burge, C.B.; Bartel, D.P. Most mammalian mRNAs are conserved targets of microRNAs. Genome Res. 2009, 19, 92-105. [CrossRef]

56. Lujambio, A.; Lowe, S.W. The microcosmos of cancer. Nature 2012, 482, 347-355. [CrossRef]

57. Ebert, M.S.; Sharp, P.A. Roles for microRNAs in conferring robustness to biological processes. Cell 2012, 149, 515-524. [CrossRef]

58. Denli, A.M.; Tops, B.B.J.; Plasterk, R.H.A.; Ketting, R.F.; Hannon, G.J. Processing of primary microRNAs by the microprocessor complex. Nature 2004, 432, 231-235. [CrossRef]

59. Gregory, R.I.; Yan, K.P.; Amuthan, G.; Chendrimada, T.; Doratotaj, B.; Cooch, N.; Shiekhattar, R. The microprocessor complex mediates the genesis of microRNAs. Nature 2004, 432, 235-240. [CrossRef]

60. Bohnsack, M.T.; Czaplinski, K.; Gorlich, D. Exportin 5 is a RanGTP-dependent dsRNA-binding protein that mediates nuclear export of pre-miRNAs. RNA 2004, 10, 185-191. [CrossRef]

61. Rodriguez, M.S.; Dargemont, C.; Stutz, F. Nuclear export of RNA. Biol. Cell 2004, 96, 639-655. [CrossRef]

62. Okada, C.; Yamashita, E.; Lee, S.J.; Shibata, S.; Katahira, J.; Nakagawa, A.; Yoneda, Y.; Tsukihara, T. A high-resolution structure of the pre-microRNA nuclear export machinery. Science 2009, 326, 1275-1279. [CrossRef]

63. Förstemann, K.; Tomari, Y.; Du, T.; Vagin, V.V.; Denli, A.M.; Bratu, D.P.; Klattenhoff, C.; Theurkauf, W.E.; Zamore, P.D. Normal microRNA maturation and germ-line stem cell maintenance requires loquacious, a double-stranded RNA-binding domain protein. PLoS Biol. 2005, 3, 1187-1201. [CrossRef]

64. Fu, Q.; Yuan, Y.A. Structural insights into RISC assembly facilitated by dsRNA-binding domains of human RNA helicase A (DHX9). Nucleic Acids Res. 2013, 41, 3457-3470. [CrossRef]

65. Chendrimada, T.P.; Gregory, R.I.; Kumaraswamy, E.; Norman, J.; Cooch, N.; Nishikura, K.; Shiekhattar, R. TRBP recruits the Dicer complex to Ago2 for microRNA processing and gene silencing. Nature 2005, 436, 740-744. [CrossRef]

66. Khvorova, A.; Reynolds, A.; Jayasena, S.D. Functional siRNAs and miRNAs exhibit strand bias. Cell. 2003, 115, 209-216. [CrossRef]

67. Bartel, D.P. MicroRNA target recognition and regulatory functions. Cell 2009, 136, 215-233. [CrossRef] [PubMed]

68. Behm-Ansmant, I.; Rehwinkel, J.; Doerks, T.; Stark, A.; Bork, P.; Izaurralde, E. mRNA degradation by miRNAs and GW182 requires both CCR4:NOT deadenylase and DCP1:DCP2 decapping complexes. Genes Dev. 2006, 20, 1885-1898. [CrossRef] [PubMed]

69. Kiriakidou, M.; Tan, G.S.; Lamprinaki, S.; De Planell-Saguer, M.; Nelson, P.T.; Mourelatos, Z. An mRNA m7G cap binding-like motif within human Ago2 represses translation. Cell 2007, 129, 1141-1151. [CrossRef] [PubMed]

70. Pillai, R.S.; Bhattacharyya, S.N.; Artus, C.G.; Zoller, T.; Cougot, N.; Basyuk, E.; Bertrand, E.; Filipowicz, W. Inhibition of translational initiation by let-7 microRNA in human cells. Science 2005, 309, 1573-1576. [CrossRef]

71. Wakiyama, M.; Takimoto, K.; Ohara, O.; Yokoyama, S. Let-7 microRNA-mediated mRNA deadenylation and translational repression in a mammalian cell-free system. Genes Dev. 2007, 21, 1857-1862. [CrossRef]

72. Petersen, C.P.; Bordeleau, M.-E.; Pelletier, J.; Sharp, P.A. Short RNAs repress translation after initiation in mammalian. Molecular Cell 2006, 21, 533-542. [CrossRef]

73. Bashkirov, V.I.; Scherthan, H.; Solinger, J.A.; Buerstedde, J.M.; Heyer, W.D. A mouse cytoplasmic exoribonuclease (mXRN1p) with preference for G4 tetraplex substrates. J. Cell Biol. 1997, 136, 761-773. [CrossRef] [PubMed]

74. Liu, J.; Rivas, F.V.; Wohlschlegel, J.; Yates, J.R.; Parker, R.; Hannon, G.J. A role for the P-body component GW182 in microRNA function. Nat. Cell Biol. 2005, 7, 1161-1166. [CrossRef] [PubMed]

75. Mihnea, D.; Baoqing, C.; Xiao, F.; George, A.C. Key questions about the checkpoint blockade-are microRNAs an answer? Cancer Biol. Med. 2018, 15, 103-115. [CrossRef]

76. Bernstein, E.; Kim, S.Y.; Carmell, M.A.; Murchison, E.P.; Alcorn, H.; Li, M.Z.; Mills, A.A.; Elledge, S.J.; Anderson, K.V.; Hannon, G.J. Dicer is essential for mouse development. Nat. Genet. 2003, 35, 215-217. [CrossRef]

77. Petri, R.; Malmevik, J.; Fasching, L.; Åkerblom, M.; Jakobsson, J. miRNAs in brain development. Exp. Cell Res. 2013, 321, 84-89. [CrossRef] [PubMed]

78. Bian, S.; Hong, J.; Li, Q.; Schebelle, L.; Pollock, A.; Knauss, J.L.; Garg, V. MicroRNA cluster miR-17-92 regulates neural stem cell expansion and transition to intermediate progenitors in the developing mouse neocortex. Cell Rep. 2013, 3, 1398-1406. [CrossRef] [PubMed]

79. Åkerblom, M.; Sachdeva, R.; Quintino, L.; Wettergren, E.E.; Chapman, K.Z.; Manfre, G.; Lindvall, O.; Lundberg, C.; Jakobsson, J. Visualization and genetic modification of resident brain microglia using lentivirus vectors regulated by microRNA-9. Nat. Commun. 2013, 4, 1770. [CrossRef]

80. Delaloy, C.; Liu, L.; Lee, J.; Su, H.; Shen, F.; Yang, G.; Young, W.L.; Ivey, K.N. MicroRNA-9 coordinates proliferation and migration of human embryonic stem cell-derived neural progenitors. Cell Stem Cell 2010, 6, 323-335. [CrossRef]

81. Ghosh, T.; Aprea, J.; Nardelli, J.; Engel, H.; Selinger, C.; Mombereau, C.; Lemonnier, T.; Moutkine, I.; Schwendimann, L.; Dori, M.; et al. MicroRNAs stablish robustness and adaptability of a critical gene network to regulate progenitor fate decisions during cortical neurogenesis. Cell Rep. 2014, 7, 1779-1788. [CrossRef] [PubMed] 
82. Hazin, A.N.; Poretti, A.; Cruz, D.D.C.S.; Tenorio, M.; Van der Linden, A.; Pena, L.J.; Brito, C.; Gil, L.H.V.; Miranda-Filho, D.B.; Marques, E.T.D.A.; et al. Computed tomographic findings in microcephaly associated with Zika virus. N. Engl. J. Med. 2016, 374, 2193-2195. [CrossRef] [PubMed]

83. McLean, E.; Bhattarai, R.; Hughes, B.W.; Mahalingam, K.; Bagasra, O. Computational identification of mutually homologous Zika virus miRNAs that target microcephaly genes. Libyan J. Med. 2017, 12, 1304505. [CrossRef]

84. Bagasra, O.; Prilliman, K.R. RNA interference: The molecular immune system. J. Mol. Histol. 2004, 35, 545-553. [CrossRef]

85. Li, Z.; Nagy, P.D. Diverse roles of host RNA-binding proteins in RNA virus replication. RNA Biol. 2011, 8, 305-315. [CrossRef]

86. Chavali, P.L.; Stojic, L.; Meredith, L.W.; Joseph, N.; Nahorski, M.S.; Sanford, T.J.; Sweeney, T.R.; Krishna, B.A.; Hosmillo, M.; Firth, A.E.; et al. Neurodevelopmental protein Musashi-1 interacts with the Zika genome and promotes viral replication. Science 2017, 88, 83-88. [CrossRef] [PubMed]

87. Garcez, P.P.; Nascimento, J.M.; de Vasconcelos, J.M.; Madeiro da Costa, R.; Delvecchio, R.; Trindade, P.; Loiola, E.C.; Higa, L.M.; Cassoli, J.S.; Vitória, G.; et al. Zika virus disrupts molecular fingerprinting of human neurospheres. Sci. Rep. 2017, 7, 40780. [CrossRef]

88. Zeng, J.; Dong, S.; Luo, Z.; Xie, X.; Fu, B.; Li, P.; Liu, C.; Yang, X.; Chen, Y.; Wang, X.; et al. The Zika virus capsid disrupts corticogenesis by suppressing dicer activity and miRNA biogenesis. Cell Stem Cell 2020, 27, 618-632. [CrossRef] [PubMed]

89. Bhagat, R.; Prajapati, B.; Narwal, S.; Agnihotri, N.; Adlakha, Y.K.; Sen, J.; Mani, S.; Seth, P. Zika virus E protein alters the properties of human fetal neural stem cells by modulating microRNA circuitry. Cell Death Differ. 2018, 25, 1837-1854. [CrossRef] [PubMed]

90. Castro, F.L.; Geddes, V.E.V.; Monteiro, F.L.L.; Gonçalves, R.M.D.T.; Campanati, L.; Pezzuto, P.; Paquin-Proulx, D.; Schamber-Reis, B.L.; Azevedo, G.S.; Gonçalves, A.L.; et al. MicroRNAs 145 and 148a are upregulated during congenital Zika virus infection. ASN Neuro. 2019, 11, 1-14. [CrossRef] [PubMed]

91. Tabari, D.; Scholl, C.; Steffens, M.; Weickhardt, S.; Elgner, F.; Bender, D.; Herrlein, M.L.; Sabino, C.; Semkova, V.; Peitz, M.; et al. Impact of Zika virus infection on human neural stem cell microRNA signatures. Viruses 2020, 12, 1219. [CrossRef]

92. Dang, J.W.; Tiwari, S.K.; Qin, Y.; Rana, T.M. Genome-wide integrative analysis of Zika-virus-infected neuronal stem cells reveals roles for microRNAs in cell cycle and stemness. Cell Rep. 2019, 27, 3618-3628. [CrossRef]

93. Azouz, F.; Arora, K.; Krause, K.; Nerurkar, V.R.; Kumar, M. Integrated microRNA and mRNA profiling in Zika virus-infected neurons. Viruses 2019, 11, 162. [CrossRef]

94. Kozak, R.A.; Majer, A.; Biondi, M.J.; Medina, S.J.; Goneau, L.W.; Sajesh, B.V.; Slota, J.A.; Zubach, V.; Severini, A.; Safronetz, D.; et al. MicroRNA and mRNA dysregulation in astrocytes infected with Zika virus. Viruses 2017, 9, 297. [CrossRef]

95. Islam, M.S.; Khan, M.A.; Murad, M.W.; Karim, M.; Islam, A.B.M.M.K. In silico analysis revealed Zika virus miRNAs associated with viral pathogenesis through alteration of host genes involved in immune response and neurological functions. J. Med. Virol. 2019, 91, 1584-1594. [CrossRef] [PubMed]

96. Sharma, N.; Verma, R.; Kumawat, K.; Basu, A.; Singh, S.K. MiR-146a suppresses cellular immune response during Japanese Encephalitis virus JaOArS982 strain infection in human microglial cells. J. Neuroinflamm. 2015, 12, 30. [CrossRef] [PubMed]

97. Jiang, H.; Bai, L.; Ji, L.; Bai, Z.; Su, J.; Qin, T.; Wang, G.; Balasubramaniam, V.; Wang, X.; Cui, M.; et al. Degradation of microRNA miR-466d-3p by Japanese Encephalitis virus NS3 facilitates viral replication and interleukin-1b expression. J. Virol. 2020, 94, 1-20. [CrossRef] [PubMed]

98. Kanokudom, S.; Vilaivan, T.; Wikan, N.; Thepparit, C.; Smith, D.R.; Assavalapsakul, W. MiR-21 promotes Dengue virus serotype 2 replication in HepG2 cells. Antiviral Res. 2017, 142, 169-177. [CrossRef]

99. Pareek, S.; Roy, S.; Kumari, B.; Jain, P.; Banerjee, A.; Vrati, S. MiR-155 induction in microglial cells suppresses Japanese Encephalitis virus replication and negatively modulates innate immune responses. J. Neuroinflamm. 2014, 11, 97. [CrossRef]

100. Ashraf, U.; Zhu, B.; Ye, J.; Wan, S.; Nie, Y.; Chen, Z.; Cui, M.; Wang, C.; Duan, X.; Zhang, H.; et al. MicroRNA-19b-3p modulates Japanese Encephalitis virus-mediated inflammation via targeting RNF11. J. Virol. 2016, 90, 4780-4795. [CrossRef]

101. Muñoz-jordán, J.L.; Laurent-rolle, M.; Martínez-sobrido, L.; Ashok, M.; Ian, W.; Mun, J.L. Inhibition of alpha/beta interferon signaling by the NS4B protein of flaviviruses. J. Virol. 2005, 79, 8004-8013. [CrossRef] [PubMed]

102. Liang, Q.; Luo, Z.; Zeng, J.; Chen, W.; Foo, S.S.; Lee, S.A.; Ge, J.; Wang, S.; Goldman, S.A.; Zlokovic, B.V.; et al. Zika virus NS4A and NS4B proteins deregulate Akt-mTOR signaling in human fetal neural stem cells to inhibit neurogenesis and induce autophagy. Cell Stem Cell 2016, 19, 663-671. [CrossRef] [PubMed]

103. Grant, A.; Ponia, S.S.; Tripathi, S.; Balasubramaniam, V.; Miorin, L.; Sourisseau, M.; Schwarz, M.C.; Sánchez-Seco, M.P.; Evans, M.J.; Best, S.M.; et al. Zika virus targets human STAT2 to inhibit type I interferon signaling. Cell Host Microbe 2016, 19, 882-890. [CrossRef] [PubMed] 